\title{
Policy Options for Low and Sustainable Lending Rates in Nigeria
}

\author{
Olumide S. Ayodele, PhD \\ Department of Economics, University of Calabar, Nigeria \\ ayodeleolumide@gmail.com +2348064010500 \\ Frances N. Obafemi, PhD \\ Department of Economics, University of Calabar, Nigeria \\ francesobafemi@yahoo.co.uk.+234803743619 \\ Akongwale, Sabastine \\ Research Division, Public Finance and Macroeconomics, \\ National Institute for Legislative Studies, Abuja, Nigeria \\ Saba.akongwale@googlemail.com +234 7066378795
}

\section{Doi:10.5901/mjss.2013.v4n3p147}

\section{Abstract}

The average prime and maximum lending rates were as high as 16.96 per cent 24.65 per cent in 2012. Conversely, the weighted average savings and term deposit rates stabilized at 5.30 per cent between July and October 2012. The level of interest rate is important in the mobilization and allocation of funds in an economy. Therefore, it is not surprising why the current high lending interest rate regime in Nigeria remains a source of concern to policy makers. This paper articulates the factors explaining the present high cost of funds in the Nigerian banking system and policy options useful in achieving low and sustainable interest rate objectives in Nigeria. Using descriptive analysis covering the 1990s, when the interest rate was fully deregulated in Nigeria, up until 2012; the paper notes that high interest rate is largely driven by high sunk costs due to dearth of infrastructure. It recommends a strong legal framework for addressing loan defaults. In this direction, review of the legal clause which gives undue advantage to borrowers is critical. A time frame for the disposal of loan default cases need to be set as prolonged litigations at the instance of loan defaulters usually stall the process of take over and the consequent auctioning of borrowers' collateral by lenders to recover their loans. In addition, provision of constant electricity is necessary to significantly reduce bank cost of funds.

\section{Introduction}

Cost of fund is a critical variable in the loanable funds market as it plays a key role both in mobilization and efficient allocation of financial resources in an economy. It is defined by Harvey $(2003 ; 50)$ as the interest rate associated with borrowing money. Hence, deposit rate is the interest cost or interest expense a financial institution must bear for the use of funds mobilized. The lending interest rate however is the yearly price charged by a lender to a borrower in order for the borrower to obtain loan, usually expressed as a percentage of the total amount loaned. It is the price a borrower must pay so as to enjoy the use of cash he does not own, and the return a lender enjoys for deferring his consumption or parting with such liquidity. Hence both cost of funds and interest rate relate to lending and borrowing and affect the amount of consumption, saving and investment in an economy.

Savings institutions pay interest to people who deposit funds with the institution, and borrowers pay interest on their loans. Like any other price in a market economy, supply and demand determine the interest rate. The demand for money depends on how much money people and organizations want to have to meet their everyday expenses, how much they want to save to protect themselves against times when their income may fall or their expenses may rise, and how much they want to borrow to invest.

Banks generally take risks when they lend to their customers, including other banks, but risk taking differs across banks as some engage in more risks than their capital could bear while others are more prudent. The banks that extend riskier loans assume higher credit risk and may easily be distressed with little mismanagement. In the process of buying and selling money by banks, the price is primarily determined by the cost of funds. The monetary policy of the Central 
Bank of Nigeria (CBN) influences the availability and cost of money in the economy. Too much money leads to inflation. Too little results in high interest rates that make it more expensive to invest and may lead to a slowdown in the national economy. The apex bank uses its monetary policy instruments to influence movement of reserves of the banks, which affect the banks in their credit operations and in turn influence the cost and availability of loanable funds. Essentially, as pointed out by Fukasawa(2003) a low real interest rates and eventually long term rates can have a broad and deep impact on the economy such as stimulating business investment and allowing for an expansion of capacity and efficiency. Similarly, a decline in interest rates may positively affect business investment in albeit in a different way. Given that Certificates of Deposits and other types of savings account now yield lower returns; thus wealth holders may switch their portfolios to more variable -rate investments such as stocks. This increase demand may cause a stock market rally. A decline in interest rates can induce consumers to increase their purchase of durable goods which can also stimulate output in an economy. Importantly, a decline in the in the interest rate should also be in the interest of the government; especially, given its impact on government finances. This is very important given that lower interest rates will reduce the cost of servicing domestic debt.

Global interest rates have been historically low for many years now. On the contrary, lending rate has been very high in Nigeria. The average prime lending rate ranged between 16.96 per cent in July 2012 to 16.48 per cent in October 2012. Also, the average maximum lending rate increased from 23.45 to 24.65 per cent during the period. Conversely, the weighted average savings and term deposit rate stabilized at 5.30 per cent during the period. The Minister of Finance and Coordinating Minister for the Economy was reported to have agreed with participants at a Consolidative Forum with private sector operators and civil societies organizations on the 2013 budget that interest rates charged by banks in the economy are too high and inimical to business survival.

Public opinion in the recent past has attributed the slow growth of the industrial and manufacturing sectors to the lending processes of banks. However, banks have argued that the high interest rate regime is due to high cost of operation. Initially, cost of mobilizing funds were claimed to be too high. For instance, before the bank consolidation, over $70 \%$ of the banks' deposits came from the public sector of the economy, necessitating the scramble by banks for government funds, notwithstanding the high deposits rates of between $20 \%$ and $25 \%$ allegedly demanded by government ministries and agencies that placed such funds. Globally, banks and other financial institutions without exempting Nigeria compete for households' saving deposits because of tenor stability and by paying interest to the savers and lend same funds to borrowers at higher rate than they pay to savers.

Furthermore, banks blame the upward trend in cost of funds on the failure of the government to honour its obligations under the tripartite agreement on interest rate moderation with the Central Bank of Nigeria and the banks, a situation that allegedly dislocated the envisaged gains from the agreement. This tripartite agreement reached on October 22, 2002 contained a decision to lower interest rate to the point where lending rates should not exceed $4 \%$ above the Minimum Rediscount Rate (MRR) which has been replaced by the Monetary Policy Rate (MPR) as at December 2006. The quantity, quality, cost and availability of loanable funds have continued to constrain the expansion of businesses in Nigeria, reflecting the small size and weak capital base of most of the banks as well as high cost of funds for credit creation. For example most of the banks that were supposed to drive financial intermediation in Nigeria resulting in less financial deepening in the financial sector and necessitated the banking sector reforms that commenced on July 6, 2004.

Giving the background to the banking sector in Nigeria, Soludo (2004: 5) highlighted poor credit policies and administration, high incidence of delinquent loans and ethical standards as well as undercapitalization/insolvency and illiquidity as some of the major problems within the banking industry, with obvious implications on the state of banking sector soundness. These factors were driving the cost of funds at the inter-bank lending market before the commencement of the banking sector consolidation. Efforts by the CBN at ensuring safe and sound banking practices that would safeguard depositors' funds made it very imperative to beef up the standard capital adequacy requirements for the banks to encourage them to maintain a certain level of net worth by shoring up their shareholders' fund to a minimum of N25 Billion with effect from January 12006 . Recently, the CBN discovered that some of the consolidated banks have high non-performing loans in their portfolios that could cause systemic crises. The expanded discount window (EDW) was used to bail out the ailing commercial banks by CBN. The current high interest rate regime in the economy should be a source of concern to policy makers, the CBN, banks and to the ultimate fund users in the economy as it runs counter to the objectives of banking sector consolidation.

Outside the framework set by the Central Bank of Nigeria on what constitutes the cost of funds in its monetary policy guidelines, borrowers always complain that most banks are not transparent in their computation of cost of funds, hence the high interest rates charged to customers. According to the borrowers, customers are always accosted with high lending rate which the banks attributed to high cost of funds, while the methodology used to arrive at the cost of the funds 
remained a mystery and exploitative to the borrowers. The argument of excessive hedging by the banks becomes very overwhelming. It is therefore imperative that an understanding of the critical factors that drive these costs and their transmission dynamics be understood as a first step to reducing interest rates.

This paper articulates the issues involved in the determination of cost of funds by banks in Nigeria, emphasises the items considered by banks and the processes involved in the calculations, analyses the data in order to ascertain the critical factors that affect cost of funds in Nigerian banking system. It also assesses the level of compliance with the relevant policy on interest rate and by extension cost of funds and makes recommendation for policy options that would influence the reduction of interest rates within the economy. The paper uses both descriptive and empirical analysis which covers the deregulation period, especially from 1990s when the interest rate was fully deregulated up to 2010.

For analytical purposes, the rest of the paper is structured into four sections. Section 2 reviews the literature on the determinants of cost of funds while Section 3 contains the discussion of the trend in lending and deposit interest rate levels and spread in Nigeria and selected countries. Section 4 identifies factors driving high cost of fund in Nigeria and Section 5 recommends some policy options and concludes the paper.

\section{Literature Review}

The loanable funds theory of the rate of interest developed by Knut Wicksell, a Swedish Economist, in 1898 has been central to the theory of cost of funds and interest rates. Philbeam(1998) asserts that the loanable funds approach views the interest rate as being determined by the forces of supply and demand for loanable funds in the capital markets. The theory posits that investments and savings determine the long term level of interest rates, while short-term rates are determined by financial and monetary conditions in the economy. It revealed that the intersection of the supply and demand for loanable funds determines the interest rate and by extension cost of funds, while the equilibrium interest rate is such that it clears both the money market and the loanable funds market. The rise in the supply of loanable funds necessitates downward trend in cost of fund and interest rate, all other things being equal. On the other hand, the increase in the demand for loanable funds exerts pressure on the available loanable funds resulting in a rise in cost of funds and interest rate.

Fisher (1930) stressed that at the economy level, the rise in the income level increases the level of savings, which in turn increases the quantum of loanable funds. However, economic agents could take more debts because of increase in expected future income. Also an increase in the proportion of savings held in the form of interest earning assets compared to non interest earning assets resulting from intermediation, could led to an increase in the supply of loanable funds. Stiglitz (2001) noted that capital adequacy standards may induce banks to engage in gambling behaviour which involves a cost. Because capital is expensive, banks are only able to pay depositors relatively low interest rates, which he equated to lowering their marginal returns to deposits. The banks' risky behaviour seems to be higher during economic deregulation and liberalization when economic activities are very high and dynamic, and bank capital is found to be inadequate Nwaoba (2006). Stiglitz further noted that the published capital-to-asset ratios of banks are, therefore frequently overstated by officials of banks that are anxious to conceal bad loans.

In a comparative analysis, Angbazo and Saunders (1997) found that the cost of funds to large banks increased after Federal Deposit Insurance Corporation Improvement Act (FDICIA) of 1991 was implemented in the United States, suggesting that bank creditors believed that the likelihood of a bigger bank benefiting from the "too-big-to-fail" policy which was perceived from the congressional testimony of the comptroller of the currency in September 1984. Its counterpart in the country, Nigeria Deposit Insurance Corporation (NDIC) Act was promulgated under the laws of the Federation of Nigeria 1990 for the purpose of insuring deposit liabilities of licensed banks and some other financial institutions such as MFBs and MFIs in Nigeria. The NDIC premium which is about $0.94 \%$ of total deposits of a bank, forms part of the computable items used to arrive at the total cost of funds of banks in Nigeria.

Keynes (1936) identified two sets of services performed by the modern banker, namely, supplying a substitute for state money by acting as a clearing house and transferring current payments backwards and forwards between different customers by means of book entries on the credit and debit sides. The banker also acts as a middleman in a particular kind of lending, receiving deposits from the public which is employed in purchasing securities, or making loans to individuals, industry and trade, mainly to meet the demand for working capital.

Following from the view of this writer, and under the inter-bank lending arrangement, the banks borrow funds from the central bank depending on the ruling cost of funds. The borrowers of the funds from the banks in turn pay liquidity premium to the banks to induce them to lend long, and size of the liquidity premium increases with the time to maturity of the loan. 
In line with Drury (2000) and Mouck(1997) arguments, banks lend to customers who invest the money in projects that yield return in excess of the opportunity cost of the investment; where opportunity cost of the investment is also known as either the minimum required rate of return, cost of capital, discount rate or interest rate. Drury had argued that a firm should operate at a point where marginal cost is equal to marginal revenue, and marginal cost is represented by the marginal cost of capital normally used to finance projects. The study by Mouck, on the other hand, highlighted the fact that firms produce goods and services at the lowest possible cost while maximizing profits.

However, Brock (2000) observed that banks find it difficult to monitor their borrowers, while deficient internal controls on both initial and ongoing loan evaluations lure banks to lend even in circumstances in which repayment seems unlikely. Brock further observed that bank managers sometimes resort to accounting gimmicks such as double-gearing, whereby a bank lends money to a firm within its group so that the firm can buy an equivalent amount of the bank's stocks. The bank's reported capital rises by that amount, but the group's capital remains the same, with consequences for financial sector soundness and stability. Proposals have also been made to incorporate exchange rate movements. This approach acknowledges that borrowing in foreign currency may produce a gain as the cost of funds declines with depreciation of that foreign currency.

Monetary policy is one of the two principal means (the other being fiscal policy) by which governments in a market economy regularly influence the direction of overall economic activity. It is a central bank's mandate to influence the availability and the cost of money and credit in an economy. Apart from the open market operations in the money market by the CBN, occasioned by the need to achieve a desired level of money supply in the economy and also to raise money for development purposes (as mostly experienced in the less developed countries), the CBN lends to the banks that wish to borrow money from it at its lending rate (the MRR), now replaced with the Monetary Policy Rate (MPR). The banks on their part are expected by the Banks and Other Financial Institutions Act1991 (as prescribed in section 13) to maintain minimum cash reserves ratio against unexpected withdrawals (BOFIA 1995). The banks of course resort to borrowing from the Central Bank when they run below such stipulated ratio. They raise their own cost of funds and interest rates in line with the Central Bank lending rate, and also hold more cash reserves when CBN rate increases.

Reserves requirement that emanate from Central bank's change of policy affect monetary and financial conditions. A reduction in the reserve requirement increases the quantum of cash held by the banks and therefore makes more funds available for extension of credit to investors. In the traditional Keynesian view, a fall in money supply will result to a rise in interest rates and high cost of capital leading to a decline in investment spending. Ajayi (2001) stressed that a change in policy leads to a change in money supply. For a given money demand, this leads to changes in market interest rates and in bank loan rates for borrowers which may affect investment decisions and changes in deposit rates. Ultimately, this may affect the choice between present and future consumption. He stated that changes in interest rate affect not only the cost of credit but also the cash flows of debtors and creditors as well as alter the marginal cost of borrowing leading to changes in investment and saving and thus aggregate demand.

Interest rates were fully deregulated in Nigeria in 1990 and banks thereafter set their costs of credit and cost of funds according to market forces. According to Ndekwu (1993), three arguments were put up to justify this favourable behaviour towards market forces. They relate to the real rate of interest (nominal rate must sufficiently adjust for the rate of inflation), tight monetary policy (growth of credit and money supply is restricted) and money market behaviour (pressure on interbank funds in the market pushes up interest rates). In 2004, former President Olusegun Obasanjo urged banks to bring down their lending interest rate and costs and be specific in their charges rather than hedging with administrative and book-keeping charges that are 'annoying, inhuman, criminal, anti-growth and anti- development'. He noted that banks put up all sorts of arguments and provide several technical rationalizations and justifications for high double-digit interest rates, which stifles creativity, discourages investments (especially the development of small and medium enterprises) suffocates businesses and intimidates the ordinary person in a developing nation like Nigeria (Obasanjo, 2004).

Obasanjo's view was at the heels of the persistent complaints of the Manufacturers' Association of Nigeria (MAN) about very high interest rates charged by the banks and the maturity pattern of the loan facility extended to their members, where they are expected to repay the loans within 90 days as if they are traders. MAN had argued that the conversion cycle of raw materials to money is within seven months range which does not give any comfort for a 90 day loan facility. As expected, the banks argued that the prevailing high interest rates were the direct effects of rising cost of funds in the financial markets as well as inflation rate.

The expected rate of inflation also plays a crucial role in the determination of the cost of funds and interest rate, especially the real interest rate represented by the Fisher's equation; $r=i+p e$, where $r=$ real interest rate, $I=$ the nominal interest rate and $p_{\mathrm{e}}$ is the expected inflation rate. Harvey(1986) pointed out that this development is due to the fact that 
fund lenders require positive real expected returns ( not just expected returns) from lending their funds while borrowers pay positive real cost for access to loanable funds. Investors therefore find it uneconomical to lend money at less than the expected rate of inflation since changes in expectations about inflation have a significant influence on the rate of interest.

The ability to pay the agreed interest rate is usually one of the conditions of inter- bank lending. This is because a banker borrows money with an obligation to repay on demand or after an agreed period; and he lends funds (extends credit) with an obligation on the part of the borrower to repay under stipulated terms and conditions which include the maturity period. The banker therefore borrows money and lends if and when these terms and conditions are mutually acceptable and fulfilled. The cost of funds to a lending bank, therefore depends on such terms as the duration of the loan (maturity period), risk assessment of the borrower and the expected rate of return from yields on treasury bills or bonds.

Cost of funds is therefore affected by the expected level of default risk that is, the risk that the borrower or an issuer of debt securities will default on all or part of the commitments in the loan contract. Agene (1995) stated that the cost of obtaining liquidity is a function of market conditions and degree of risk, (both interest and exchange rates and credit risks), which are reflected in the balance sheet of the banks. A bank can still be overexposed in terms of risk arising from excessive lending of funds or booking credit notwithstanding the level of its capital base. The distress phenomenon experienced by banks in the first half of 1990s was largely due to this factor. A larger percentage of Nigerian borrowers, including banks are prone to loan default while the sanction for such act is not stiff enough to deter them. Linked to credit risk is the degree of liquidity and duration of the loan. These factors also determine the rate to be charged by investors of funds because the less liquid the security or collateral, the higher the charge to the borrowing agency, while longer duration implies higher risk that also attract higher charges. On the other hand, higher credit rating of an economic agent gives it an advantage to borrow funds at a relatively lower charge.

For a banking institution, cost of regulation consists of opportunity and operating costs that do arise from the activities or changes in activities that are required by regulation (Ellienhausen, 1998). Opportunity costs could occur for a bank when a regulation prevents it from engaging in profitable activity. Another opportunity cost is the interest forgone due to prohibition on investing reserves in interest bearing assets. Having been cited by Ellienhausen and using a similar cost accounting methodology to estimate the operating costs at banks in the US, Darnell(1980), Mckinskey and company(1992) and Grant (1992b) studied the regulatory costs of banks in three categories namely direct labour cost, other direct cost and overhead expenses.

Darnell estimated that a banks' operating expense cost in 1979 represented 13.7 percent 0 fits total non-interests expenses of which its cost of complying with consumer regulations alone was 5.9\% of non-interest expense. Mckinsey and company in 1991 studied incremental ongoing regulatory cost at four large commercial banks covered by deposit insurance and estimated that the average cost of complying with all sixty regulations was $6.1 \%$ of non-interest expenses, of which the most costly was the deposit insurance estimated at $4.1 \%$ of non-interest expenses. The average cost of complying with consumer regulations was $0.8 \%$ of non- interest expense. Grant Thornton studying nine banks in 1991 made an estimated regulation cost to be within the average of $14.2 \%$ of non interest expenses of which consumers regulation cost was $8.6 \%$ of non- interest expenses. The three studies above revealed that consumer regulations are especially costly for all banks.

In all the three cases, the various factors that determine the cost of funds would include the demand and supply indices for loanable funds; inflation rate; inflation expectations; interbank funds rates; risk perceptions; the credit worthiness of the borrower; savings rate; the prevailing lending rate; maturity period; cash reserve requirements for banks; liquidity ratio; minimum rediscount rate (monetary policy rate); growth of bank credit to the economy; growth of money supply; the credibility of the government's macroeconomic policy; the capital base of the financial intermediaries; the interaction between fiscal and monetary policies; the rate of economic growth; political factors; economic agents' perception about future and overheads, as well as international factors like the interest rates in the rest of the world and exchange rate regime adopted by the concerned countries.

\section{Trend In Lending and Deposit Interest Rates Levels and Spread in Nigeria and Selected Countries}

Nigeria has experimented with different interest rate policy options, yielding different results over time. Prior to the Structural Adjustment era, Nigeria operated a regulated interest rate policy. By the early 1990s it embraced full liberalisation of its monetary policy. The experiences of most countries that have embarked on financial liberalisation has not always been a success. Economic literature is awash with links between financial liberalisation and financial sector instability. Studies such Demirguc-Kunt and Detragiache,(1999); Demetriades, (1999) and Arestis and 
Demetriades(1999) all point out the lack of success in the operation and implementation of a policy of market determined interest rates in most developing countries

Financial liberalisation can be traced to the seminal works of Mckinon(1973) and Shaw (1973) and extended and popularised by Fry(1997). The concepts gained near absolute support by the Bretton Woods Institutions - " the Washington Concensus". Financial liberalisation has been flaunted as a means of enhancing levels of financial savings and investment as well as improvement in resource allocation and general benefits of a more dynamic and productive investment. Nevertheless, ironically, most emerging economies have not experienced the benefits of financial liberalisation.

Figure 1a: Nigeria, Historical Trend of Interest Rate Spread

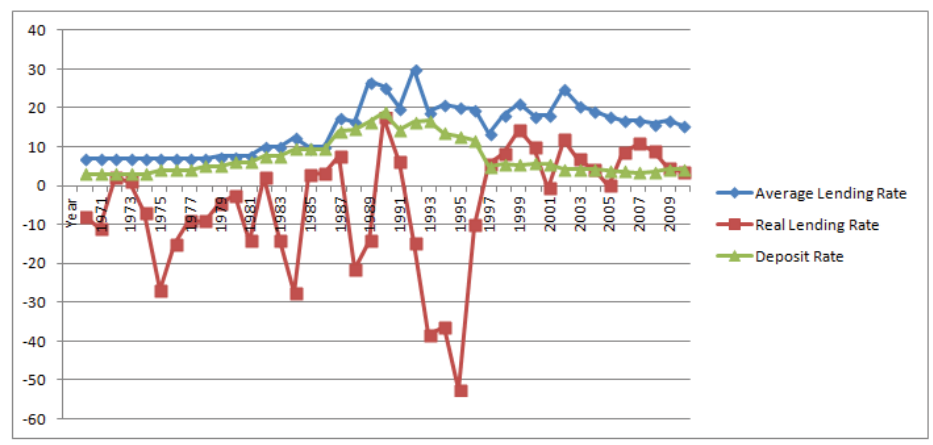

Figure 1b:

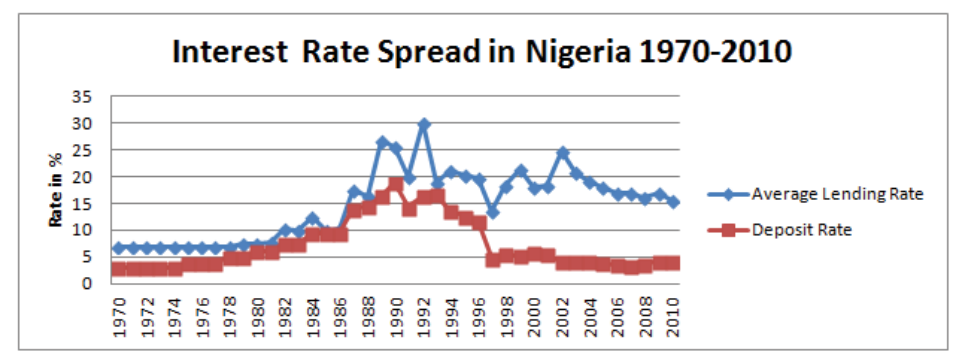

As can be seen from the figures $1(a \& b)$ above, prior to the liberalisation of its interest rate, the interest rate spread in Nigeria (Average lending rate - average deposit rate) was minimal. With the advent of the deregulation and liberalisation policies of the 1990s, this gap (interest rate spread) widened. This posed problems for prospective borrowers. Similarly, the real lending rate which is the nominal lending rate, after discounting for inflation was at its lowest at the peak of the liberalisation policies in Nigeria. This is an indicator that policies aimed at addressing the high cost of borrowing in Nigeria must also seek to address inflation in Nigeria. During this period the real lending rate was mostly negative.

Figure 2 shows the behaviour of interest rates in Nigeria, vis-a -vis other comparator countries. The choice of countries was based on factors such as similarity policies thrust over time; structure of the economy; and size of the economy. 
Table 1:

\begin{tabular}{|l|l|}
\hline Comparator Country & Reason(s) \\
\hline Kenya & $\begin{array}{l}\text { Like Nigeria has gone through both regulated financial sector and IMF's financial } \\
\text { liberalisation. }\end{array}$ \\
\hline Algeria & $\begin{array}{l}\text { An OPEC member, like Nigeria sometimes is awash with oil revenue, which may } \\
\text { necessitate Sterilisation of excess money supply from oil revenue. }\end{array}$ \\
\hline South Africa & $\begin{array}{l}\text { Similarity in the size of the economy. Both of them are the two largest economies in } \\
\text { Africa. }\end{array}$ \\
\hline Unite Kingdom & An advanced economy, with an independent Central Bank. \\
\hline
\end{tabular}

Figure 2: Nigeria vs. Comparator Countries: Interest Rate Spread Pattern.

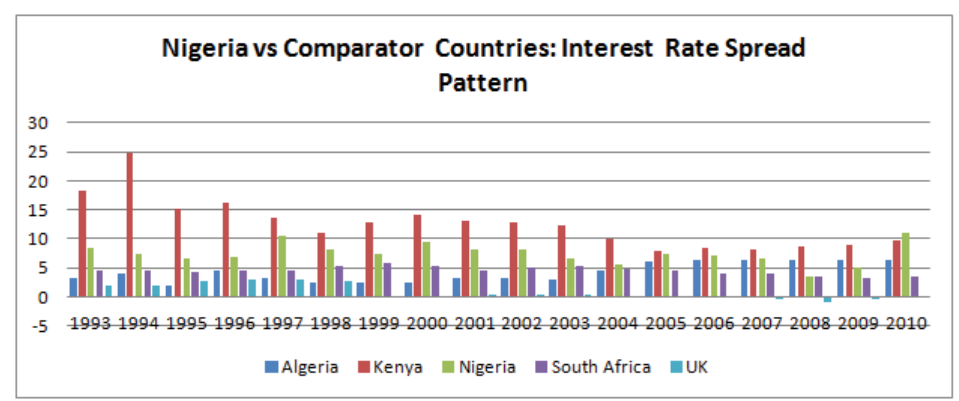

From figure 2 above, it can be seen that Nigeria and Kenya had the highest interest rate spread during the period under study. The United Kingdom had the lowest interest rate spread during this period. Interestingly, Kenya and Nigeria had operated similar monetary Policy during the period in question.

Given the failure of finanancial liberalisation, some countries such as Kenya returned to re-regulation in its quest to create rational and objective targets for interest. (IPAR, 2001). However, any attempt to address this must entail a balance between the two extremes of unchecked financial liberalisation and financial repression. This may entail measures such as uncoupling the the composition and computation of the benchmark interest rates/ the prime rate from which the commercial banks derive/ compute their lending rates. Faced with similar situation of high interest rates coupled with a high interest rates spread, following its its implemntation of financial liberalisation policies in the 1990, the Kenyan government approached this by with a legislation that brought a re-relugulation legislation Known as the Central Bank of Kenya Act (CAP 491). The leglsation required the followoing:

- that the maximum interest rate charged by financial institution shall not exceed three percentage points above the 91 day Treasury Bill Rate

- that the financial institutions pay a minimum of $70 \%$ of the Treasury Bill rate as interest on saving.

As pointed out by (IPAR, 2000), it was anticipated that that the legislation will achieve the following:

(i) Reduce the interest rate paid by commercial borrowers;

(ii) Raise the interest rate paid on savings; and

(iii) Narrow the spread earned by the bank and non- bank finanancial institutions

From fig (2) above, it can be observed that the interest rate spread in Kenya did drop between 2000 and 2010. This may be attributted to its implementation of its policy of re-regulation. However, this may not work in Nigeria, given the difference in the structure of both economies and the fact that the 91 days TB rates in Nigeria, is above 10\% - a rate that is already higher than the banks' deposit rates.

In the Nigerian scenerio, as earlier pointed out, the lending rates take their benchmark from the Monetary Policy Rate (MPR) which is fixed by the monetary Policy Committtee. This rate replaced the Minimum Rediscount Rate (MRR). The Monetery Policy Rate (MPR) is fixed for every sixty days by the Monetary Policy Committee(MPC), usually, with $\mathrm{a}+$ or - corridor that has ranged from -200 basis points to +400 basis points over time. This corridor may bee too wide, given its potential cascading impact on the final cost of borrrowing charged by financial institutions.

The computation of the cost of funds stem from the division of interest expense by the volume of interest bearing liabilities. However, the cost of new debt capital is after tax interest cost of raising new debt. This description of computing 
cost of funds has bearing globally on the interest rates and that suffice to establish a fact of figures as to the trend in lending rates particularly in Nigeria and some notable countries.

The creditworthiness of the borrower is one reason why some kinds of loans have higher rates of interest than some do. Short-term loans made to people or businesses with a long history of stable income; stable employment; and who have assets that can be pledged as collateral that will become the bank's property if a loan is not repaid will receive the lowest interest rates.

In United Sates for instance, well-established firms such as AT\&T often pay what is called the bank's prime ratethe lowest available rate for business loans-when they borrow money. New, start-up companies pay higher rates because there is a greater risk they will default on the loan or even go out of business. Other kinds of loans also have greater default risk, so banks and other lenders charge different rates of interest.

Mortgage loans are backed by the collateral of the property the loan was used to acquire. If someone does not pay his or her mortgage, the bank reserves the right to sell the property that was pledged as collateral and to collect the proceeds as payment for what is owed. That means the bank's risks are lower, so interest rates on these loans are typically lower, too. The money that is loaned to people who do not pay off the balances on their credit cards every month represents a greater risk to banks, because no collateral is provided. Because the bank does not hold any title to the consumer's property for these loans, it charges a higher interest rate than it charges on mortgages. The higher rate allows the bank to collect enough money overall so that it can cover its losses when some of these riskier loans are not repaid.

If a bank makes too many loans that are not repaid, it will go out of business. The effects of bank failures on depositors and the overall economy can be very severe, especially if many banks fail at the same time and the deposits are not insured. In the United States, the most famous example of this kind of financial disaster occurred during the Great Depression of the 1930s, when a large number of banks failed. Many other businesses also closed and many people lost both their jobs and savings.

Bank failures are fairly rare events in the U.S. economy. Banks do not want to lose money or go out of business, and they try to avoid making loans to individuals and businesses that will be unable to repay them. In addition, a number of safeguards protect U.S. financial institutions and their customers against failures. The Federal Deposit Insurance Corporation (FDIC) insures most bank and savings and loan deposits up to $\$ 100,000$. Government examiners conduct regular inspections of banks and other financial institutions to try to ensure that these firms are operating safely and responsibly.

In Nigeria however, high interest rate has been a major contention in banks and more especially in MFBs. It can be said that more funds can bring down interest rates and loan tenure extension in the financial system. Interest rates are currently five to six per cent per month in the microfinance industry. Also state the yearly rate. To an average end fund user, it may be slightly lower or higher depending on the particular product. Invariably, this constitutes part of some challenges stakeholders encounter in microfinance sector. Funding is a major issue. So, the more funds you have, the more you can extend the tenure of the loan you give, as well as reduce the interest rate. What we need to understand is that microfinance is a very cost intensive marketing aspect because you go to customers to collect proceeds, unlike the conventional banks. That brings added cost to the operations. And what it will cost you to chase a loan of N100 will apparently be the same it would cost you to chase a loan of N1 million.

Over the years, intervention fund that could come from fund donors either from the government agencies or international NGOs are not easily come by due to many requirements that could enable harnessing this loanable funds to the fund users in the economy. Also, the interbank lending rate that normally hovers around $8 \%$ sometimes falls below this margin depending on the fund available to the banks through these agencies and institutions. However, the single digit interest rate regime only stops at the interbank lending market leaving the key users of this fund to their fate.

General opinion will support a deposit rates to bank at reduced interest rate from government institutions such that the current efforts by Bank of Industry (BOI) and NERFUND will enhance growth in lending to the poor in the economy. It worth to be mentioned that as at 2006 when the first few microfinance banks given license to operate in the banking subsector, ( Integrated MFB, MIC Mfb and few others) an average interest rate on micro business loan was as high as $8 \%$ flat per month averaging $96 \%$ per year. This trend was forced down during the year 2007/2008 due to the forces of market competition and loanable fund supply in the economy. 


\section{Framework for Cost of Fund Computation in Nigeria}

It is important to discuss the major determinants of the high cost of loanable funds in Nigeria, both in conventional banks and down to the MFBs and MFIs. To this end, the major approaches that have been used by the CBN in computing cost of funds determinants in the Nigerian financial system are presented. According to the CBN, banks are expected to use weighted average cost of capital in line with international banking practice. This equals the sum of the multiple of the proportion of debt capital and the cost of debt capital on one hand, and the sum of the proportion of equity capital and the cost of equity capital on the other. For banks in the ordinary sense of it, the ratio of Naira amount paid as interest in a particular month to the average naira amount of the funds for that month constitutes the average weighted cost of funds ratios for that month

The cost items in the CBN framework includes banks' interest cost on the different types of deposit liabilities, borrowings from the inter-bank funds market, payments in respect of deposit insurance premium and cost due to reserve requirement; while overhead cost are excluded in the framework. (CBN 2004:17). The cost of item in the framework of a typical bank in Nigeria, therefore includes the following; current liabilities such as commercial paper rediscounted; interbank takings, as well as current savings account deposits, fixed deposits and bank certificates in the form of unique products of the bank that customer invest in. Other considerations include cost of energy generation, currency movement, currency sorting, public relations and stationeries. Also, expenses incurred on payment of salaries and general maintenance of the banks' fixed assets which form the bulk of the overhead costs that the CBN directed should be excluded from computing banks' cost of funds. These are incurred as operating expenses, which are eventually added to the following to arrive at total cost of funds:

1. NDIC premium ( $15 / 16$ of $1 \%$ of total deposits of the bank or $0.94 \%$

2. Calculated percentage of cash reserve

3. Calculated percentage of other liquid assets

Ratnayake $(2004 ; 4)$ observed that some banks have the ability to canvass low cost funds more easily than others due to certain advantages they have in providing solution for customer needs. Any advantage gained by a bank in low cost of funds, therefore, contributes to its profit either directly or by leveraging through other business deals.

\subsection{Deposit Insurance Premium}

This protects the payment system from disruption. It is an anchor for public confidence in the banking system. That is, because a portion of deposits are guaranteed, depositors need not rush to the bank to withdraw funds if the banks capacity to cover them becomes questionable. It is intended to prevent the financial stability associated with runs on the banks that can bring down even sound institutions. Under deposit insurance, banks issue a class of liabilities for which most balances, especially for small depositors, are fully insured by the Nigeria Deposit Insurance Corporation (NDIC). Computation

The NDIC Act 2006 guarantees payment of deposits up to the maximum insured sum $(N 500,000.00)$ to a depositor in deposit money banks and $\mathrm{N200,000}$ to a depositor in MFBs and primary mortgage institutions) in the event of the failure of a participating financial institution. Balances in all deposit accounts held in the same right and capacity by a depositor in all branches of the closed insured institution, net of outstanding debts, are aggregated to determine the maximum insured amount. The deposit insurance separates the depositor from the credit risks of the bank which are assumed by the NDIC. In essence, when a bank issues a deposit, it engages in two transactions ; it issues a risk-free (government-insured) liability to e depositor and purchases an insurance contract from the deposit insurance corporation to cover the credit risks associated with the priority of the deposit claim (Hutchison 2005;3). The cost of deposit insurance is paid from insurance premium, which are passed on to the banking system and the banks in turn include them in the computation of cost of funds.

\subsection{Overhead Cost}

High cost of funds and overhead costs make pricing by banks costly. Banks do endeavour to recover their annual overhead expenditure from business every year since they are of recurrent nature. This category includes a host of cost such as advertising costs, data processing services, software development costs, certain legal fees, branch networking, information technology and auditing. A bank with small capital and small branch network will present a higher cost of funds since it has to attract high end deposits due to lack of a large branch network with low overheads. Overhead costs 
for bank $A, B$ and $D$ in the representative table (Appendix 1.) amounted to N354.00Million, N856.0million and N142.0million respectively while bank $C$ did not include it in accordance with the central bank's directives. The high overhead cost posted by bank B with volume of deposits and other funds of N79,948.5million shows that the bank is either rendering spurious returns to the central Bank or there is an element of mismanagement.

\subsection{Cash Reserve Requirements and Adjustments}

The reserve adjustments by banks allow for the effect of changes in reserve requirements on a bank's deposits and for changes in proportion of deposits subject to different reserve requirements. The CBN can stimulate or tighten available bank credit and the ability of banks to lend by raising or lowering the amount of required reserves. Thus, the inclusion of adjustment for cash reserve deposits in the framework for the computation of cost of funds. Further analysis of the table derived from the returns of four deposit money banks to the CBN show that bank $C$ complied with the central bank directive of excluding overheads from the computation of cost of funds (See Appendix 1).

\section{Policy Recommendations, Summary and Conclusion}

\subsection{Recommendations}

In general, due to the fact that cost of fund is dependent upon credit risk of the borrowers among others, it is noted that credit risk is a major consideration for extending loans to borrowers but the sanctions for defaults on loans are weak. The legal clauses for default on loans which give a sort of leverage to the defaulting persons require legal strengthening. The laws must be able to capture in its details, time frame for disposal of related cases because prolonged litigations at the instance of the borrowers, usually stall the take-over option and consequent auctioning of borrowers' collaterals by banks in an effort to recover their exposures.

Importantly, there is need for new laws empowering the CBN to act in the midst of this high cost of funds. This can be achieved vis the introduction of mangaged liberalisation of the interest rate. This may entail measures such as uncoupling the the composition and computation of the benchmark interest rates/ the prime rate from which the commercial banks derive/ compute their lending rates. This has has been practised with considerable success as was the case in Kenya, albeit Nigeria may need to use some other approach other than that employed by kenya.

The failed bank law ought to be strengthened and enforced so that borrowers instantly brought to book so that lenders do not suffer unduly in the hands of loan defaulters. National Assembly and CBN should work in conjunction to enact laws that will aim at the dual objectives making it difficult for loan beneficiaries to default and easy for lenders to be able to recover bad loans.

The penalties attached to issuing a dud cheque which is being strengthened now will be applauded if the law is well invoked to ensure that any one prosecuted, rightly face the wrath of the law.

It worth to be mentioned that inadequate infrastructure is a bane of low general business turnout in Nigeria economy and as such makes the business environment very harsh and unfriendly. For instance, weak energy sector that has been crawling for years is endangering investment boom, a problem for banks and other businesses that depend largely on electricity to run numerous IT equipments and systems. This encourages high tariff regime on electricity, which has translated high tariff regime in the telecommunications sector that the banks actually required to undertake efficient and effective banking transactions. No doubt, alternative energy sources however are necessitated with high cost of fuel that definitely reflects in their cost of funds and interest rates charges. Hence government should as a matter of importance provide effectively constant energy supply such that cost of doing business is generally moderated and by implication reduce average cost of fund charged by the deposit money banks

It is recommended that the CBN need to continue to mediate in the movement of interest rate within Nigeria economy. In 2006, Bankers' committee directed that banks should clearly spell out upfront, the rates a prospective credit client would be expected to pay was a timely one. The banks were expected to also make open all sundry charges not above $2 \%$ per annum in addition to the actual interest rate before drawdown. These transparent initiatives were expected to ensure customers are well informed of any charge to be paid for before signing agreement whether to take the loan or not. Moreover, the downward adjustment in key ratios such as liquidity and cash reserve ratios are determinant of cost of funds in the Nigeria banks. It can also be inferred that continuous policy formulation and implementation on means to reduce credit failures in the economy and rigorous pursuit of deflationary policy stance by the CBN will continue to encourage reduction in banks' cost of fund. 


\subsection{Summary and Conclusions}

This paper focuses on the main factors responsible for the cost of funds by banks in Nigerian financial sectors. The normal framework for the computations of cost of funds by banks in Nigeria includes interest expense as the percentage of average volume of funds per annum, premium payment in deposit insurance as percentage of average volume of funds per annum and adjustments for cash reserve deposits, while some banks include overheads which were excluded by the CBN. Some of the variables that were considered in determining cost of funds included liquidity ratio, money supply and its growth rate, credit risk of the borrowers, growth of bank credit; cash reserve requirements, loan to deposit ratios, prime lending rate, and real GDP growth rate. Using econometric analysis, the contribution of these factors can be confirmed. The paper revealed further that high cost of funds is driven by increase in the demand for credit in the banking system. The mix of government fiscal policy regime and monetary policy measures and influences cost of funds and interest rates.

With respect to banks deviation from the tripartite agreement of 2002, on the interest rate benchmark by banks; due to lack of compliance, the directives of Bankers' committee for banks to spell out their rates openly to public was able to address this trend. Besides, it was expected that higher banks' deposit base resulting from bank consolidation would result in a decline in the banks' effective average cost of funds. This however, has not been the case. In addition to the above, cost of fund will decline if the credit risk is reduced by discouraging loan default by borrowers through stringent laws, adequate infrastructure, especially in the area of energy supply, is provided by government to reduce cost of doing business in Nigeria; and stability in the national policy is guaranteed to minimize uncertainties. In the final analysis, the continuous policies initiations that will reduce credit failures and rigorous pursuit of deflationary policy stance by the Central Bank of Nigeria will continue to encourage reduction in the cost of funds by banks in Nigeria.

Appendix 1: Framework for Cost of Fund Computation

\begin{tabular}{|c|c|c|c|c|c|c|c|c|c|}
\hline$S / N$ & Details & Bank A & $\%$ & Bank B & $\%$ & Bank C & $\%$ & Bank D & $\%$ \\
\hline 1 & $\begin{array}{l}\text { volume of deposits and other funds i.e } \\
\text { leverage of opening \& closing balances } \\
\text { (N'Million) }\end{array}$ & $80,041.70$ & & $79,948.50$ & & $139,623.00$ & & $51,241.30$ & \\
\hline 2 & $\begin{array}{l}\text { Interest expense for the month } \\
\text { (N'Million) }\end{array}$ & 171.3 & & 639.5 & & 881.4 & & 68.6 & \\
\hline 3 & $\begin{array}{l}\text { Deposit insurance premium payable } \\
\text { during the month (N'Million) }\end{array}$ & 34.4 & & 61.6 & & 109.1 & & 29.7 & \\
\hline 4 & $\begin{array}{l}\text { Overhead cost of funds in the month } \\
\text { (N"Million) }\end{array}$ & 354 & & 856.8 & & & & 142.5 & \\
\hline 5 & $\begin{array}{l}\text { Interest expense (2) as a \% of average } \\
\text { volume of funds per annum }\end{array}$ & & 2.6 & & 9.6 & & 7.6 & & 1.6 \\
\hline 6 & $\begin{array}{l}\text { Deposit insurance premium (3) as \% of } \\
\text { average volume of funds per annum }\end{array}$ & & 0.5 & & 0.9 & & 0.9 & & 0.7 \\
\hline 7 & $\begin{array}{l}\text { Overheads cost (4) as \% of average } \\
\text { volume of funds in the months per } \\
\text { premium }\end{array}$ & & 5.3 & & 13 & & & & 3.3 \\
\hline 8 & $\begin{array}{l}\text { Average cost of funds in \% per } \\
\text { annum }(5+6+7)\end{array}$ & & 8.4 & & 23 & & 8.5 & & 5.6 \\
\hline 9 & Adjustments for cash reserve deposits & & 1 & & 0.9 & & 3.1 & & 0.1 \\
\hline 10 & Effective average cost of funds $(8+9)$ & & 9.4 & & 24 & & 11.6 & & 5.7 \\
\hline
\end{tabular}

Source: Banking Analysis System (Monthly Returns by Banks)

\section{References}

Adam Christopher, M (2001) "Exchange Rates, volatility and the cost of capital"; Austarlian Graduate School Management Agene, C.E. (1995), The principles of modern Banking; Gene Publications, Abuja and Lagos

Angbazo, Lazaru and Saunders, Anthony (1997) "The effects of TBTF Deregulation on Bank cost of funds"; The Wharton School, Working papers $97-125$ 
Brock, Philip, I. (2000) "Financial Safety Net: What drives the persistent competitiveness of small banks" Federal Reserve System.

Central Bank of Kenya Act (CAP 491).

Central Bank of Nigeria (1991) BOFIA Act No 25 of 1991(amended)

Central Bank of Nigeria (1993) Annual Reports and Statements of Accounts

Central Bank of Nigeria (1996) Monetary POLICY Circular No 30 of 1996 (as amended)

Central Bank of Nigeria (2002) "Report of The Special Technical Sub-Committee on Interest Rates Moderation" 260th Meeting of the Bankers' committee; April 30th

Central Bank of Nigeria (2003) "The Supply and Demand for Loanable funds" in Contemporary Economic policy issues in Nigeria; ed O.J. Nnanna, etal

Central Bank of Nigeria (2005) Bank Analysis System (BAS)

Darnell, Jerome C (1980) "A study of the cost of complying with Government Regulations" Report prepared for the United Bank Of Denver

Elliehausen, Gregory (1998) "The cost of Bank Regulation: A Review of the Evidence": Board of Governors of the Federal Reserve System, Washington, DC. April.

Fisher Irving. (1930) "The Theory of Interest "New York; Macmillan

Harvey, Campbell, R. (1986) "Recovering Expectations of Consumption Growth from an Equilibrium Model of The Term Structure of Interest Rates". Chikago, Illinois.

Harvey Campbell, R. (2003) Hyper textual Finance Glossary

Grant Thornton (1992b) "Regulatory Burden: Phase II- Field Cost Studies"; Study prepared for the Independent Bankers Association of America. September

Institute of Policy Analysis and Research, Kenya Discussion Paper (2001)

Keynes, J.M. (1936) "The General Theory of Employment, Interest and Money"; First Harbinger Edition

Mckinsey and Company (1992) "Estimating Bank Regulatory Cost Burdens"; Presentation to Federal Reserve Officials. May

Mouck, Tom (1997) "Panglosian Capital Budgeting Theory in a complex Adaptive World", The University of New Mexico, USA, Working paper.

Nwaoba P.I (2006) "Cost of Funds Determination by Banks in Nigeria", Economic and Financial Review, Vol. 44 No.3

Obasanjo, Olusegun (2004) "Keynote Address at the Tenth Annual Conference of the Institute of Bankers of Nigeria"

Philbeam, Keith (1998) Finance and Financial Markets; Macmillan Press Ltd.; London

Ratyanake, Nimal (2004) "How Pricing Discipline can help Business and Profitability of banks"; Association of Professional Bankers, Sri Lanka

Sanusi, J. O. (2002) Keynote Address at the 4th Central Bank of Nigeria (CBN) Seminar for Finance Correspondents and Business Editors; Confluence Beach Hotel, Lokoja.

Stiglitz, Joseph E. (2001) "Principles of Financial Regulations: A Dynamic Portfolio Approach"; in The World Bank Research Observer, Vol.16, No 1 